\title{
Aromatase inhibitors in breast cancer
}

\author{
P E Lønning
}

Section of Oncology, Institute of Medicine, Haukeland University Hospital, University of Bergen, 5021 Bergen,

Norway

(Requests for offprints should be addressed to P E Lønning; Email: per.lonning @ helse-bergen.no)

\begin{abstract}
The development of aromatase inhibitors for breast cancer therapy is a result of successful translational research exploring the biochemical effects of different compounds in vivo. Studies assessing plasma oestrogen levels as well as in vivo aromatase inhibition have revealed a consistent difference with respect to biochemical efficacy between the third generation compounds (anastrozole, letrozole and exemestane) and the previous, first and second generation drugs, corresponding to the improved clinical effects of these compounds as outlined in large phase III studies. Thus, endocrine evaluation has been found to be a valid surrogate parameter for clinical efficacy. Moreover, the results from these studies have added important biological information to our understanding of endocrine regulation of breast cancer. Based on the clinical results so far, aromatase inhibitors are believed to play a key role in future adjuvant therapy of postmenopausal breast cancer patients and potentially also for breast cancer prevention. Interesting findings such as the lack of cross-resistance between steroidal and non-steroidal compounds should be further explored, as this may add additional information to our understanding of breast cancer biology.
\end{abstract}

Endocrine-Related Cancer (2004) 11 179-189

\section{Introduction}

The last decade has been a most successful era in the development of endocrine therapy of breast cancer. Improvements include the introduction of novel compounds like the selective oestrogen receptor downregulators (SERDS) (Howell et al. 2002), and further development of medical ovarian suppression in the metastatic as well as in the adjuvant setting (Klijn et al. 2001, Jakesz et al. 2002, Jonat et al. 2002).

However, the most important improvement has been the successful development of third generation aromatase inhibitors in metastatic disease and, more recently, in the adjuvant setting. The successful development of these compounds was based on careful preclinical development (Furet et al. 1993, Njar \& Brodie 1999) but, not least, careful evaluation of their in vivo endocrine effects in translational research studies assessing their ability to suppress plasma oestrogen levels, and direct assessment of their effects on in vivo aromatisation, using sensitive methods developed for such purposes (Dowsett et al. 1987, Jacobs et al. 1991, Lønning \& Ekse 1995). Studies utilising these assays confirmed the superior biochemical efficacy of the third generation compounds compared with the first and second generation inhibitors (Lønning 1996, Geisler et al. 1998, 2002).

While several contemporary reviews considering the clinical effects of these compounds have been published (Goss \& Strasser 2001, Smith \& Dowsett 2003), the aim of this paper was to discuss the endocrine and clinical achievements, together with particular emphasis on the importance of translational research in the development of these compounds.

\section{Endocrine rationale for aromatase inhibition}

Following the menopause, oestrogens are synthesised in different non-glandular tissues, including liver, bone marrow, muscle, skin, fat and connective tissue (Schweikert et al. 1976, Smuk \& Schwers 1977, Perel \& Killinger 1978, Frisch et al. 1980, Matsumine et al. 1984) as well as in benign and malignant breast tissue (Perel et al. 1982, Reed et al. 1989, Miller et al. 1990, Bulun et al. 1993). While it has been recognised for many years that the main contributor of the substrate androstenedione is the adrenal gland, there has been some controversy considering the contribution of androgens from the postmenopausal ovary. Based on more 


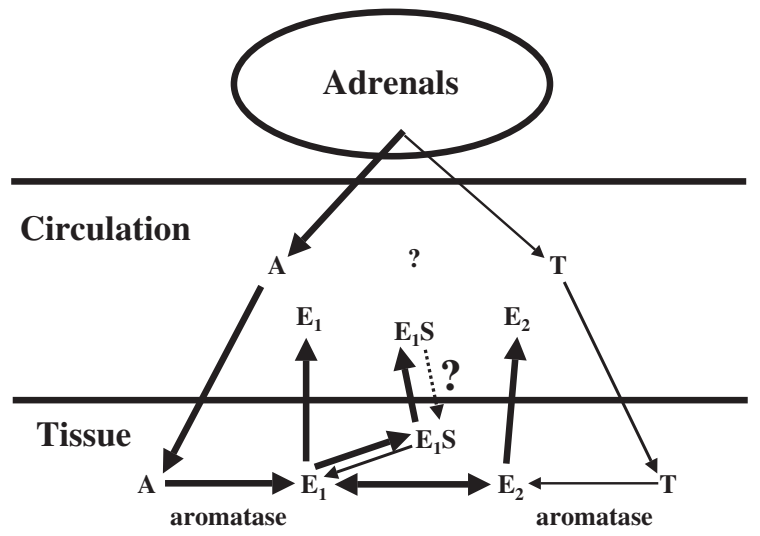

Figure 1 Pathways of oestrogen synthesis in postmenopausal women. $E_{2}$, oestradiol; $E_{1}$, oestrone; $E_{1} S$, oestrone sulphate; $A$, androstenedione, $\mathrm{T}$, testosterone.

recent evidence (Sluijmer et al. 1995, Couzinet et al. 2001), it now seems clear that the contribution of the postmenopausal ovaries to circulating androgens is, at best, minor, probably negligible. The main substrate for aromatisation is androstenedione, which is aromatised into oestrone (Fig. 1). While the aromatase enzyme may also aromatise testosterone directly to oestradiol, the fact that androstenedione levels are about fourfold higher compared with testosterone levels in postmenopausal women, and the higher affinity of the aromatase enzyme for the androstenedione substrate, contribute to making oestrone the major circulating unconjugated oestrogen in postmenopausal women (Lønning et al. 1990). While oestrone sulphate exists in higher concentrations (Geisler et al. 1997), this is an inactive conjugate that may act as a depot and (probably) a source of oestrogens to the tissue. When considering circulating oestradiol, it has been estimated that probably half the amount is converted from circulating oestrone, while the residual is produced by direct aromatisation of testosterone (Lønning et al. 1990).

An interesting subject relates to tissue versus plasma oestrogen levels in postmenopausal women. It has been recognised for decades that tissue oestradiol concentration is 10-20 higher compared with circulating oestradiol levels in postmenopausal women (Edery et al. 1980, vanLandeghem et al. 1985, Vermeulen et al. 1985, Miller et al. 1998, Geisler et al. 2001) in contrast to the findings in premenopausal women. The explanation is probably that circulating oestrogens are all synthesised in the tissue; thus, there is a passive 'gradient' from tissue toward plasma (Fig. 1), although a study in rats suggested active uptake from the circulation (Masamura et al. 1997). The fact that tumour oestradiol concentration is often higher than the concentration seen in surrounding non-malignant tissue is consistent with local synthesis but also high concentration of the 17ß-hydroxysteroid reductase in the tumours
(vanLandeghem et al. 1985, Vermeulen et al. 1985). While the aromatase enzyme expressed in different tissues is the same, a number of different promoters have been identified as playing a different role in different compartments (Chen et al. 2001, Bulun et al. 2003), suggesting potential local regulation by hormones, growth factors and interleukins (Reed et al. 1993, Zhao et al. 1995, 1996, Agarwal et al. 1996, Simpson et al. 1999, Singh et al. 1999). Notably, while tissue concentrations of oestradiol are high, we and others have found the concentration of oestrone sulphate to be somewhat lower in tissue compared with the circulation (Vermeulen et al. 1985, Geisler et al. 2001). While this may refute the hypothesis that plasma oestrone sulphate may be taken up by the tissue (Santner et al. 1986), the possibility exists that it may be rapidly metabolised to unconjugated steroids; interestingly, there is evidence that oestrone sulphate may be actively transported across the cell membrane (Pizzagalli et al. 2003). Studies evaluating the quantitative contribution of local oestrogen production in the tumours versus systemic uptake have revealed a substantial inter-individual variation (James et al. 1989, Miller 1994), suggesting that local production plays an important role in some, but not all, tumours.

\section{Compounds}

Aromatase inhibitors may be divided into two major classes, the so-called non-steroidal (previously often termed 'type 2 inhibitors') and the steroidal compounds (previously termed 'type-1 inhibitors') (Fig. 2). The nonsteroidal inhibitors belong to two different chemical classes, the so-called aminoglutethimide-like compounds, including aminoglutethimide itself and rogletimide, and triazole derivatives, including anastrazole, letrozole and vorozole. The steroidal compounds are all derivatives of androstenedione, the main substrate for the aromatase enzyme.

The two classes of compounds differ with respect to their biochemical action on the aromatase enzyme. While<smiles>C=C1CC2C(CCC3C(=O)CCC32)C2C=CC(=O)C=C12</smiles><smiles>O=C1CCC2C(=C1O)CCC1C3CCC(=O)C3CCC21</smiles><smiles>CC1(c2ccc(N)cc2)CCC(=O)NC1=O</smiles>

Aminoglutethimide
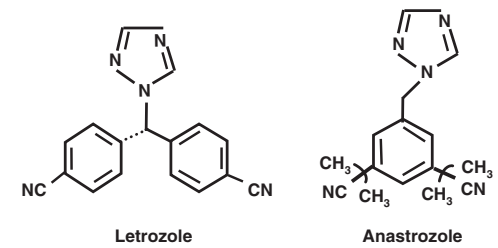

Figure 2 Chemical structure of different aromatase inhibitors. 
the non-steroidal compounds bind to the $\mathrm{p} 450$ site of the aromatase complex, the steroidal compounds bind to the substrate-binding pocket (Miller 1989). In addition, the steroidal inhibitors can bind irreversibly to the aromatase enzyme (Miller \& Dixon 2000), for which reason they are termed 'suicide inhibitors' or, more recently, aromatase inactivators. Whether the observed lack of complete cross-resistance between the compounds is related to their action on the aromatase enzyme or whether it could be due to some additional endocrine effects of the steroidal compounds is discussed later in this paper.

\section{Endocrine studies}

The efficacy of the different compounds have been assessed in in vitro studies using placental or ovarian tissue with androstenedione as substrate for the enzyme. When compared with aminoglutethimide, the more recent second and third generation compounds were found to be more potent (Batzl et al. 1996). Notably, the differences recorded in in vitro systems may not be directly translated into what may happen in vivo. For the in vivo efficacy of a compound, it should be emphasised that factors other than its direct inhibitory constant, such as total body pharmacokinetics and local tissue penetration, may be of importance.

The endocrine efficacy of different aromatase inhibitors may be assessed in two different ways. One possibility is to determine plasma oestrogen levels; alternatively, we may assess aromatisation directly by double-tracer injections of ${ }^{3} \mathrm{H}$-androstenedione and ${ }^{14} \mathrm{C}$-oestrone with determination of the isotope ratio in the oestrogens.

When considering plasma oestrogen measurements, the main limitation relates to the sensitivity of the assays. Based on a formal assessment of current methods and plasma oestrogen levels, we have concluded that it is not possible to measure plasma oestrone and oestradiol suppression below $10-15 \%$ of control levels in the majority of postmenopausal patients during treatment with the potent third generation aromatase inhibitors and inactivators, despite utilising the most sensitive radioimmunoassays (Lønning 2001). In contrast, the oestrogen conjugate, oestrone sulphate, exists in higher concentrations; here, it is possible to detect up to $99 \%$ suppression (Lønning \& Ekse 1995). The clinical relevance of this issue is illustrated in a recent paper comparing oestrogen suppression with anastrozole compared with letrozole in a cross-over study (Geisler et al. 2002). For plasma oestradiol, we found no significant difference in suppression between the two compounds due to the fact that most patients had their plasma oestradiol suppressed down to the sensitivity limit of the assays during treatment with both compounds. On the contrary, we were able to detect a significant difference between the compounds with regard to their ability to suppress plasma oestrone and, in particular, oestrone sulphate. When considering oestrone sulphate, we found mean plasma levels during treatment with letrozole to be one-third of the mean level recorded on treatment with anastrozole.

A particular problem relates to oestrogen measurements in patients during treatment with steroidal compounds, such as exemestane. When considering the fact that the dose of drug administered (25 mg/day) is probably around 25000 times the amount of total estrogens produced in a postmenopausal woman during therapy with such a compound (Lønning et al. 1990), even minor metabolites causing modest interactions in the radioimmunoassays could influence the results. Such interactions have been confirmed with respect to exemestane (Johannessen et al. 1997), and sample purification involving HPLC is always recommended for oestrogen assessment in patients during treatment with such steroidal compounds.

Assessment of in vivo aromatisation may, in principle, be done with one of two methods. One possibility is to infuse ${ }^{3} \mathrm{H}$-labelled androstenedione and ${ }^{14} \mathrm{C}$-labelled oestrone to achieve a steady-state concentration and to determine the isotope ratio in the plasma oestrone fraction (Santen et al. 1978). The second method is to administer a bolus injection of ${ }^{3} \mathrm{H}$-labelled androstenedione and ${ }^{14} \mathrm{C}$ labelled oestrone followed by urine collection for $96 \mathrm{~h}$ and determination of the isotope ratio in the oestrogen metabolites. In a collaborative programme between Professor Mitch Dowsett's group in London and our group in Bergen, we used such a method (Jacobs et al. 1991) to determine in vivo aromatase inhibition during treatment with different first, second and third generation compounds. The results are shown in Table 1. A formal assessment of this method confirmed the possibility of detecting up to $99.1 \%$ aromatase inhibition in the majority of patients (Dowsett et al. 1995). The sensitivity of the method is illustrated in the recent study comparing anastrozole with letrozole, revealing a significant difference in the degree of aromatisation between the compounds (Geisler et al. 2002). Consideration of the clinical importance of a more complete aromatase inhibition is discussed later in this paper.

\section{Clinical efficacy of second generation aromatase inhibitors/inactivators in metastatic breast cancer}

The second generation non-steroidal inhibitor fadrozole and the steroidal inactivator formestane were compared with megestrol acetate as second-line therapy and tamoxifen as first-line therapy. While all these studies 
Table 1 Aromatase inhibitors in current or previous use. The figures for the percentage aromatase inhibition are all obtained from a joint programme involving the Royal Marsden Hospital and our own institution, using the same experimental design

\begin{tabular}{|c|c|c|c|c|c|}
\hline Compound & Type & Generation & Dose & $\begin{array}{c}\text { Mean aromatase } \\
\text { inhibition } \\
(\%)\end{array}$ & Reference \\
\hline Aminoglutethimide & Inhibitor & First & 1000 mg/day & 91 & MacNeill et al. (1992) \\
\hline Fadrozole & Inhibitor & Second & $\begin{array}{l}2 \mathrm{mg} / \mathrm{day} \\
4 \mathrm{mg} / \mathrm{day}\end{array}$ & $\begin{array}{l}82.4 \\
92.6\end{array}$ & Lønning et al. (1991) \\
\hline Formestane (oral) & Inactivator & Second & $\begin{array}{l}125 \mathrm{mg} / \text { day } \\
125 \mathrm{mg} \text { bid } \\
250 \mathrm{mg} \text { od }\end{array}$ & $\begin{array}{l}72.3 \\
70.0 \\
57.3\end{array}$ & MacNeill et al. (1995) \\
\hline $\begin{array}{l}\text { Formestane } \\
\quad \text { (intramuscular) }\end{array}$ & Inactivator & Second & $\begin{array}{l}250 \mathrm{mg} / 2 \mathrm{wk} \\
500 \mathrm{mg} / 2 \mathrm{wk} \\
500 \mathrm{mg} / \mathrm{wk}\end{array}$ & $\begin{array}{l}84.8 \\
91.9 \\
92.5\end{array}$ & Jones et al. (1992) \\
\hline Anastrozole & Inhibitor & Third & $\begin{array}{l}1 \mathrm{mg} / \text { day } \\
10 \mathrm{mg} / \text { day }\end{array}$ & $\begin{array}{l}96.7 \\
98.1\end{array}$ & Geisler et al. (1996b) \\
\hline Anastrozole/letrozole ${ }^{a}$ & & & $\begin{array}{l}\text { Anastrozole }(1 \mathrm{mg} / \mathrm{day}) \\
\text { Letrozole }(2.5 \mathrm{mg})\end{array}$ & $\begin{array}{r}97.3 \\
>99.1\end{array}$ & Geisler et al. (2002) \\
\hline Letrozole & Inhibitor & Third & $\begin{array}{l}0.5 \mathrm{mg} / \mathrm{day} \\
2.5 \mathrm{mg} / \mathrm{day}\end{array}$ & $\begin{array}{l}98.4 \\
98.9\end{array}$ & Dowsett et al. (1995) \\
\hline Exemestane & Inactivator & Third & $25 \mathrm{mg} / \mathrm{day}$ & 97.9 & Geisler et al. (1998) \\
\hline
\end{tabular}

${ }^{a}$ Evaluated in the same 12 patients in a cross-over study.

bid, twice daily; od, once daily; wk, weeks; 2 wk, every second week.

included a limited number of patients by today's standards, there was no evidence of improved response rate or time-to-progression for any of these compounds compared with 'standard' therapy (Pérez-Carrión et al. 1994, Buzdar et al. 1996, Falkson \& Falkson 1996, Thürlimann et al. 1996, 1997a).

\section{Clinical efficacy of third generation aromatase inhibitors/inactivators in metastatic breast cancer}

The results from clinical studies comparing anastrozole, letrozole and exemestane with megestrol acetate or aminoglutethimide in the second-line or tamoxifen in the first-line setting have been reviewed in detail elsewhere (Lønning 2002), and only the conclusion is given here. While the results in the second-line setting are not univocal, in general there is a trend for the superiority of each compound compared with megestrol acetate and for letrozole compared with aminoglutethimide (Buzdar et al. 1998, 2001, Dombernowsky et al. 1998, Gershanovich et al. 1998, Kaufmann et al. 2000).

The results in the first-line setting seem more convincing. When considering anastrozole, there was a significant improvement for anastrozole compared with tamoxifen regarding time-to-progression in one study, while the compounds were similar in a second (Bonneterre et al. 2000, Nabholtz et al. 2000). Combining the results from the two studies, a significant superiority for anastrozole was revealed in patients harbouring oestrogen receptor-positive tumours (Bonneterre et al. 2001). Summarising the evidence, it may be concluded that anastrozole is at least as good as tamoxifen, although it may be questioned whether it could be claimed to be significantly superior in statistical terms. When considering letrozole, a large phase III study revealed superiority with respect to time-to-progression as well as response rate for letrozole compared with tamoxifen. Importantly, in that study superiority was confirmed in subgroups based on oestrogen receptor analysis, metastatic location and different parameters (Mouridsen et al. 2001). Thus, for letrozole, a clear superiority compared with tamoxifen has been confirmed.

When considering exemestane, a phase II study revealed significant superiority compared with tamoxifen (Dirix et al. 2001). However, the number of patients was small, and the results of the final phase III study in the near future are awaited.

\section{Adjuvant therapy}

The results of the large ATAC study have recently been reported (Baum et al. 2002). This study revealed the superiority of anastrozole compared with tamoxifen regarding relapse-free survival when combining local and distant relapses in the statistical analysis (Table 2). So far, no superiority for survival has been recorded but the follow-up time is short, and further analysis is 
Table 2 ATAC trial (Baum et al. 2002): Results summary

\begin{tabular}{llll}
\hline Treatment arm & Hazard ratio & $95.2 \%$ Cl & $P$ value \\
\hline DFS in ITT population & & & 0.013 \\
$\quad$ Anastrozole vs tamoxifen & 0.83 & $0.71-0.96$ & 0.8 \\
$\quad$ PAna + Tam vs tamoxifen & 1.02 & $0.89-1.18$ & 0.005 \\
DFS in ER+ population & & & 0.8 \\
$\quad$ Anastrozole vs tamoxifen & 0.78 & $0.65-0.93$ & $0.87-1.21$ \\
$\quad$ Ana + Tam vs tamoxifen & 1.02 & & 0.007 \\
Incidence of new contralateral & & $0.22-0.79$ & 0.5 \\
$\quad$ primary breast tumours & 0.42 & $0.51-1.40$ & \\
$\quad$ Anastrozole vs tamoxifen & 0.84 & & \\
Ana + Tam vs tamoxifen &
\end{tabular}

Ana, anastrozole; Tam, tamoxifen; ER+, oestrogen receptor positive; $\mathrm{Cl}$, confidence interval; ITT, intention-to-treat; DFS, diseasefree interval.

awaited. Interestingly, in that study, combined treatment with tamoxifen and anastrozole was found to be inferior compared with anastrozole monotherapy, suggesting an antagonistic effect of tamoxifen in patients on anastrozole treatment. The reason for this will be discussed later.

Of particular interest was the profound reduction of contralateral breast cancer seen in the anastrozole arm (Table 2). If this reduction is confirmed during long-term follow-up and also in other studies evaluating aromatase inhibitors for adjuvant therapy, it may suggest aromatase inhibitors as effective agents for breast cancer prevention in postmenopausal high-risk women (see later section).

Currently, several studies comparing letrozole as well as exemestane with tamoxifen given as monotherapy or sequential administration using different time-intervals are being conducted; the results of these studies are expected in the near future.

\section{Lack of cross-resistance to aromatase inhibitors and inactivators}

An interesting observation in metastatic disease has been a lack of cross-resistance between aromatase inhibitors and inactivators, now confirmed in several studies (Table 3).

In general, these studies involved treatment with an aromatase inactivator following failure on an aromatase inhibitor; one small study reported the use of anastrozole in patients failing on formestane (HarperWynne \& Coombes 1999). These studies have reported a lack of complete cross-resistance between the different compounds. While the largest study exploring exemestane in patients failing aminoglutethimide, anastrozole or letrozole revealed a small response rate $(7 \%)$, the percentage of patients achieving stable disease $>6$ months was $17 \%$, meaning that $24 \%$ of the patients benefited from having this therapy implemented following failure on the nonsteroidal inhibitor (Lønning et al. 2000). Notably, that study (Lønning et al. 2000) revealed little difference in response rates between patients who had previously failed on a third generation non-steroidal compound versus those who had failed on aminoglutethimide (20 versus $27 \%$ ). While the findings in some studies that patients failing aminoglutethimide responded to exemestane (Thürlimann et al. 1997b, Lønning et al. 2000) could be explained by a more potent aromatase inhibition with the second compound, the findings that patients may respond

Table 3 Trials evaluating sequential treatment with aromatase inhibitors/inactivators in metastatic breast cancer

\begin{tabular}{llllllll}
\hline \multicolumn{7}{c}{ Treatment and results } \\
\hline First drug & AG & AG & AG & AG & nAl & For & nAl \\
Second drug & For & For & Exe & Exe & Exe & Ana & For \\
No. of patients & 112 & 10 & 78 & 136 & 105 & 21 & 20 \\
RR second drug (\%) & 20.5 & 20.0 & 25.6 & 8.1 & 4.8 & 0 & 0 \\
RR + S.D. $\geq 6$ mo (\%) & 42.9 & 50.0 & 60.3 & 27.2 & 20.0 & 62 & 55 \\
Reference & I & II & III & IV & IV & V & VI \\
\hline
\end{tabular}

AG, aminoglutethimide; Ana, anastrozole; Exe, exemestane; For, formestane; nAl, non-steroidal third generation aromatase inhibitors (anastrozole, letrozole and vorozole); RR, response rate; S.D., $\geq 6$ months (mo). References for these studies are (I) Murray \& Pitt (1995); (II) Geisler et al. (1996a); (III) Thürlimann et al. (1997b); (IV) Lønning et al. (2000); (V) HarperWynne \& Coombes (1999); (VI) Carlini et al. (2001). 
to formestane after failing aminoglutethimide (Murray \& Pitt 1995), exemestane after failing anastrozole or letrozole (Lønning et al. 2000) and, importantly, the observations of a durable stable disease in patients exposed to formestane after failing third generation compounds such as anastrozole and letrozole (Carlini et al. 2001) suggest that there may be alternative explanations. Notably, treatments with exemestane as well as formestane by the oral route have been shown to suppress plasma sex hormone-binding globulin levels (Dowsett et al. 1992, Johannessen et al. 1997). This is probably related to the androgenic effects of these compounds. About 70$80 \%$ of all breast cancers express the androgen receptor (Lea et al. 1989). Androgens have been shown to have antiproliferative effects on breast cancer cell lines (Ando et al. 2002), and were used as breast cancer therapy before the implementation of the contemporary drugs (Nosaquo 1960). Future studies, looking at gene expression profiles in tissue obtained from patients during treatment with the different compounds, may solve this interesting question.

\section{Correlation between degree of oestrogen suppression and clinical efficacy of treatment with aromatase inhibitors}

An important question is whether there is a correlation between response among individual patients and the degree of oestrogen suppression. From a methodological point of view, there are several problems in addressing this question. One issue is the correlation between plasma and intra-tumour oestrogen levels. The ratio between tissue and plasma oestrogen levels varies among individuals (Geisler et al. 2001). To determine tumour oestrogen levels before and during therapy is time and resource consuming; thus, only a limited number of studies including a small number of patients have been conducted so far (Reed et al. 1991, Miller et al. 1998, Geisler et al. 2001, Miller \& Dixon 2001). While it seems that in general the degree of tissue oestrogen suppression is of the same magnitude as the suppression of plasma oestrogen levels (Geisler et al. 2001), there is no direct linear correlation between the degree of tissue and plasma oestrogen suppression among individual patients.

Two studies have addressed potential differences in oestrogen suppression among responders and non-responders to aromatase inhibitors. In the first study conducted two decades ago, Santen et al. (1982) found no difference in the degree of oestrogen suppression between the two groups. In the more recent study conducted by an Italian group (Bajetta et al. 2000), somewhat higher pretreatment oestrogen levels in responders compared with nonresponders and somewhat higher percentage suppression were found. However, the fact that mean oestrogen suppression in the different groups varied between 35 and $60 \%$ in contrast to $80-90 \%$ aromatase inhibition revealed by tracer studies (Jones et al. 1992) raises the possibility of non-specific interaction in the hormone assays. Dowsett et al. (1984) found a slight increase in oestrogen and androgen levels in patients relapsing on treatment with aminoglutethimide; however, this was probably due to a non-specific stress reaction.

Clearly, such studies suffer the problem of method sensitivity with respect to tissue as well as plasma oestrogen levels as mentioned above (Lønning 2001). Due to the fact that individual tumours express aromatase activity to a different degree and the finding that tumours may utilise circulating versus locally produced oestrogens to a different degree, this illustrates potential method limitations about correlating plasma oestrogen levels with clinical outcome. Taking into consideration the manifold of mechanisms potentially responsible for endocrine resistance in receptor-positive breast cancers (Geisler \& Lønning 2001), it seems unlikely that studies comparing the degree of oestrogen suppression with clinical outcome may add significantly to our understanding. In practice, the only surrogate parameter that could be used for practical purposes in such large-scale studies may be plasma oestrone sulphate (Lønning 2001).

On the contrary, the finding that neither formestane nor fadrozole improved therapeutic efficacy compared with megestrol acetate or tamoxifen, while the third generation aromatase inhibitors and inactivators revealed superiority compared with conventional therapy, clearly suggest a difference in clinical efficacy between those compounds inhibiting in vivo aromatisation by $80-90 \%$ and those causing about $98 \%$ inhibition.

In conclusion, it seems that a more complete aromatase inhibition is associated with a better clinical outcome although it is difficult to correlate these parameters in individual patients for the reasons mentioned above.

\section{Future directions}

Third generation aromatase inhibitors have revealed their superiority in advanced breast cancer. An interesting question is whether treatment of this condition may be further improved. While the third generation compounds inhibit in vivo oestrogen production by $>98 \%$, experimental data have shown that MCF-7 cells exposed to low concentrations of oestradiol over time may adapt to and achieve mitogenic stimulation by oestradiol at a concentration of about $10^{-4}$ of that required for the mother cell lines (Lippman et al. 1976, Masamura et al. 1995). While this suggests that more potent drugs could be beneficial, clinical evaluation of such compounds would be difficult 
for several reasons. One critical factor would be to evaluate their endocrine effects in vivo; considering the sensitivity of today's assays for hormone measurement as well as in vivo aromatase assessment, it would not be possible to discriminate the biochemical efficacy of such potent compounds from today's third generation aromatase inhibitors/inactivators.

Interestingly, the in vitro experiments mentioned above (Lippman et al. 1976, Masamura et al. 1995) revealed that growth stimulation by oestradiol in culture expressed a 'bell-shaped' curve; thus, high concentrations inhibited cell growth. Notably, 'hypersensitised' cells also expressed a bell-shaped curve, suggesting that oestradiol, at a concentration that would stimulate growth of wildtype cells, would inhibit growth of the 'sensitised' ones. Oestrogens administered in pharmacological doses were used for breast cancer therapy before the introduction of antioestrogens and aromatase inhibitors (Binnie 1944, Haddow et al. 1944, Ingle et al. 1981). Postulating that some patients developing acquired resistance to aromatase inhibitors may actually be 'sensitised', we administered diethyltstilboestrol to 32 patients previously exposed to a median of four endocrine regimens. An objective response was obtained in ten patients, with another two patients experiencing stable disease for $>6$ months duration (Lønning et al. 2001). The findings illustrate that some patients becoming resistant to aromatase inhibitors still harbour a hormone-sensitive tumour and may benefit from further endocrine treatment.

The results from the ATAC study in the adjuvant setting are exciting, and the follow-up results from this study as well as studies conducted with other aromatase inhibitors are eagerly awaited. Important issues would be not only whether aromatase inhibitors and inactivatiors reveal superiority with respect to tamoxifen regarding long-term survival, but also whether there could be any difference between the compounds and also whether any type of administration (such as sequential administration of tamoxifen followed by an aromatase inhibitor) may reveal superiority compared with monotherapy.

The findings that the selective oestrogen receptor modulators or SERMs (tamoxifen and raloxifene) reduced breast cancer incidence suggest potential for endocrine therapy as a prevention strategy, particular for postmenopausal women with a high risk of developing breast cancer. The fact that plasma oestrogen levels (Dorgan et al. 2002) as well as bone and breast density (Boyd et al. 1995, Zhang et al. 1997), which may be considered surrogate markers of long-term oestrogen exposure, relate to subsequent breast cancer risk have substantiated the importance of postmenopausal oestrogen levels to subsequent breast cancer development. The recent meta-analysis (Key et al. 2003) revealing a strong correlation between body mass index and plasma oestrogen levels in postmenopausal women raises the interesting question as to whether prevention should be 'pharmacological' or more directed at 'life-style interventions'. It is likely that such issues may be important questions for the medical community as well as health service systems in the future.

\section{References}

Agarwal VR, Bulun SE, Leitch M, Rohrich R \& Simpson ER 1996 Use of alternative promoters to express the aromatase cytochrome p450 (CYP19) gene in breast adipose tissues of cancer-free and breast cancer patients. Journal of Clinical Endocrinology and Metabolism 81 3843-3849.

Ando S, De Amicis F, Rago V, Carpino A, Maggiolini M, Panno ML \& Lanzino M 2002 Breast cancer: from estrogen to androgen receptor. Molecular and Cellular Endocrinology 193 121-128.

Bajetta E, Zilembo N, Bichisao E, Martinetti A, Buzzoni R, Pozzi P, Bidoli P, Ferrari L \& Celio L 2000 Tumor response and estrogen suppression in breast cancer patients treated with aromatase inhibitors. Annals of Oncology 11 1017-1022.

Batzl C, Hausler A, Schieweck K, Lang M \& Trunet P 1996 Pharmacology of nonsteroidal aromatase inhibitors. In Hormone-Dependent Cancer, pp 155-168. Eds J Pasqualini \& B Katzenellenbogen. New York: Marcel Dekker Inc.

Baum M, Buzdar AU, Cuzick J, Forbes J, Houghton J, Klijn JGM, Sahmoud T \& Grp AT 2002 Anastrozole alone or in combination with tamoxifen versus tamoxifen alone for adjuvant treatment of postmenopausal women with early breast cancer: first results of the ATAC randomised trial. Lancet 359 2131-2139.

Binnie GG 1944 Regression of tumors following treatment by stilboestrol and X-ray therapy, with notes on cases of breast tumour which regressed with stilboestrol alone. British Journal of Radiology 17 42-45.

Bonneterre J, Thurlimann B, Robertson JFR, Krzakowski M, Mauriac L, Koralewski P, Vergote I, Webster A, Steinberg M \& von Euler M 2000 Anastrozole versus tamoxifen as first-line therapy for advanced breast cancer in 668 postmenopausal women: results of the tamoxifen or arimidex randomized group efficacy and tolerability study. Journal of Clinical Oncology 18 3748-3757.

Bonneterre J, Buzdar A, Nabholtz J-M, Robertson J, Thürlimann B, von Euler M, Sahmoud T, Webster A \& Steinberg M 2001 Anastrozole is superior to tamoxifen as first-line therapy in hormone receptor positive advanced breast carcinoma. Cancer 92 2247-2258.

Boyd NF, Byng JW, Jong RA, Fishell EK, Little LE, Miller AB, Lockwood GA, Tritchler DL \& Yaffe MJ 1995 Quantitative classification of mammographic densities and breast cancer risk: results from the Canadian national breast screening study. Journal of the National Cancer Institute 87 670-675.

Bulun SE, Price TM, Aitken J, Mahendroo MS \& Simpson ER 1993 A link between breast cancer and local estrogen biosynthesis suggested by quantification of breast adipose tissue aromatase cytochrome $\mathrm{p} 450$ transcripts using 
competitive polymerase chain reaction after reverse transcription. Journal of Clinical Endocrinology and Metabolism 77 1622-1628.

Bulun SE, Fang ZJ, Gurates B, Tamura M, Yilmaz B, Amin S \& Yang SJ 2003 Aromatase in health and disease. Endocrinologist 13 269-276.

Buzdar AU, Smith R, Vogel C, Bonomi P, Keller AM, Favis G, Mulagha M \& Cooper J 1996 Fadrozole HCL (CGS-16949A) versus megestrol acetate treatment of postmenopausal patients with metastatic breast carcinoma. Results of two randomized double blind controlled multiinstitutional trials. Cancer 77 2503-2513.

Buzdar AU, Jonat W, Howell A, Jones SE, Blomqvist CP, Vogel CL, Eiermann W, Wolter JM, Steinberg M, Webster A \& Lee D 1998 Anastrozole versus megestrol acetate in the treatment of postmenopausal women with advanced breast carcinoma. Results of a survival update based on a combined analysis of data from two mature phase III trials. Cancer 83 1142-1152.

Buzdar A, Douma J, Davidson N, Elledge R, Morgan M, Smith R, Porter L, Nabholtz J, Xiang X \& Brady C 2001 Phase III, multicenter, double-blind, randomized study of letrozole, an aromatase inhibitor, for advanced breast cancer versus megestrol acetate. Journal of Clinical Oncology 19 3357-3366.

Carlini P, Frassoldati A, DeMarco S, Casali A, Ruggeri EM, Nardi M, Papaldo P, Fabi A, Paoloni F \& Cognetti F 2001 Formestane, a steroidal aromatase inhibitor after failure of non-steroidal aromatase inhibitors (anastrozole and letrozole): is a clinical benefit still achievable? Annals of Oncology 12 1539-1543.

Chen SU, Zhou DJ, Yang C, Okubo T, Kinoshita Y, Yu B, Kao YC \& Itoh T 2001 Modulation of aromatase expression in human breast tissue. Journal of Steroid Biochemistry and Molecular Biology 79 35-40.

Couzinet B, Meduri G, Lecce M, Young J, Brailly S, Loosfelt H, Milgrom E \& Schaison G 2001 The postmenopausal ovary is not a major androgen-producing gland. Journal of Clinical Endocrinology and Metabolism 86 5060-5066.

Dirix L, Piccart MJ, Lohrish C, Beex L, Nooij M, Cameron D, Biganzoli L, Cufer T, Yague C, Duchateau L, Lobelle J \& Paridaens R 2001 Efficacy of and tolerance to exemestane (E) versus tamoxifen (T) in 1st line hormone therapy (HT) of postmenopausal metastatic breast cancer (MBC) patients (pts): a European Organisation for the Research and Treatment of Cancer (EORTC Breast Group) phase II trial with Pharmacia and Upjohn. Proceedings of the American Society for Clinical Oncology 2029 a.

Dombernowsky P, Smith I, Falkson G, Leonard R, Panasci L, Bellmunt J, Bezwoda W, Gardin G, Gudgeon A, Morgan M, Fornasiero A, Hoffmann W, Michel J, Hatschek T, Tjabbes T, Chaudri HA, Hornberger U \& Trunet PF 1998 Letrozole, a new oral aromatase inhibitor for advanced breast cancer: double-blind randomized trial showing a dose effect and improved efficacy and tolerability compared with megestrol acetate. Journal of Clinical Oncology 16 453-461.

Dorgan JF, Longcope C, Franz C, Stanczyk FZ, Chang LC, Stephenson HE, Falk RT, Kahle L, Miller R, Tangrea JA, Campbell WS, Schatzkin A, Key TJ, Allen DS, Fentiman LS, Moore JW, Wang DY, Dowsett M, Thomas HV, Hankinson SE, Toniolo PG, Akhmedkhanov A, Koenig K, Shore RE,
Zeleniuch-Jacquotte A, Berrino F, Muti P, Micheli A, Krogh V, Sieri S, Pala V, Venturelli E, Secreto G, Barrett-Connor E, Laughlin GA, Kabuto M, Akiba S, Stevens RG, Neriishi K, Land CE, Cauley JA, Kuller LH, Helzlsouer KJ, Alberg AJ, Bush TL, Comstock GW, Gordon GB \& Miller SR 2002 Endogenous sex hormones and breast cancer in postmenopausal women: reanalysis of nine prospective studies. Journal of the National Cancer Institute 94 606-616.

Dowsett M, Harris AL, Smith IE \& Jeffcoate SL 1984 Endocrine changes associated with relapse in advanced breast cancer patients on aminoglutethimide therapy. Journal of Clinical Endocrinology and Metabolism 58 99-104.

Dowsett M, Goss PE, Powles TJ, Hutchinson G, Brodie AMH, Jeffcoate SL \& Coombes RC 1987 Use of the aromatase inhibitor 4-hydroxyandrostenedione in postmenopausal breast cancer: optimization of therapeutic dose and route. Cancer Research 47 1957-1961.

Dowsett M, Mehta A, King N, Smith IE, Powles TJ, Stein RC \& Coombes RC 1992 An endocrine and pharmacokinetic study of four oral doses of formestane in postmenopausal breast cancer patients. European Journal of Cancer 28 415-420.

Dowsett M, Jones A, Johnston SRD, Jacobs S, Trunet P \& Smith IE 1995 In vivo measurement of aromatase inhibition by letrozole (CGS 20267) in post menopausal patients with breast cancer. Clinical Cancer Research 1 1511-1515.

Edery M, Goussard J, Dehennin L, Scholler R, Reiffsteck J \& Drosdowsky MA 1980 Endogenous oestradiol-17ß concentration in breast tumours determined by mass fragmentography and by radioimmunoassay: relationship to receptor content. European Journal of Cancer 17 115-120.

Falkson CI \& Falkson HC1996 A randomised study of CGS 16949A (fadrozole) versus tamoxifen in previously untreated postmenopausal patients with metastatic breast cancer. Annals of Oncology 7 465-469.

Frisch RE, Canick JA \& Tulchinsky D 1980 Human fatty marrow aromatizes androgen to estrogen. Journal of Clinical Endocrinology and Metabolism 51 394-396.

Furet P, Batzl C, Bhatnagar A, Francotte E, Rihs G \& Lang M 1993 Aromatase inhibitors: synthesis, biological activity, and binding mode of azole-type compounds. Journal of Medical Chemistry 36 1393-1400.

Geisler J \& Lønning P 2001 Resistance to endocrine therapy of breast cancer: recent advances and tomorrows challenges. Clinical Breast Cancer 1 297-308.

Geisler J, Johannessen DC, Anker G \& Lønning PE $1996 a$ Treatment with formestane alone and in combination with aminoglutethimide in heavily pretreated cancer patients: clinical and endocrine effects. European Journal of Cancer 32A 789-792.

Geisler J, King N, Dowsett M, Ottestad L, Lundgren S, Walton P, Kormeset PO \& Lønning PE $1996 b$ Influence of anastrozole (Arimidex ${ }^{\circledR}$ ), a selective, non-steroidal aromatase inhibitor, on in vivo aromatisation and plasma oestrogen levels in postmenopausal women with breast cancer. British Journal of Cancer 74 1286-1291.

Geisler J, Lien EA, Ekse D \& Lønning PE 1997 Influence of aminoglutethimide on plasma levels of estrone sulphate and dehydroepiandrosterone sulphate in postmenopausal breast 
cancer patients. Journal of Steroid Biochemistry and Moleular Biology 63 53-58.

Geisler J, King N, Anker G, Ornati G, DiSalle E, Lønning PE \& Dowsett M 1998 In vivo inhibition of aromatization by exemestane, a novel irreversible aromatase inhibitor, in postmenopausal breast cancer patients. Clinical Cancer Research 4 2089-2093.

Geisler J, Detre S, Berntsen H, Ottestad L, Lindtjørn B, Dowsett M \& Lønning PE 2001 Influence of neoadjuvant anastrozole (Arimidex) on intratumoral estrogen levels and proliferation markers in patients with locally advanced breast cancer. Clinical Cancer Research 7 1230-1236.

Geisler J, Haynes B, Anker G, Dowsett M \& Lønning PE 2002 Influence of letrozole (Femara) and anastrozole (Arimidex) on total body aromatization and plasma estrogen levels in postmenopausal breast cancer patients evaluated in a randomized, cross-over-designed study. Journal of Clinical Oncology 20 751-757.

Gershanovich M, Chaudri HA, Campos D, Lurie H, Bonaventura A, Jeffrey M, Buzzi F, Bodrogi I, Ludwig H, Reichardt P, O'Higgins N, Romieu G, Friederich P \& Lassus M 1998 Letrozole, a new oral aromatase inhibitor: randomised trial comparing $2.5 \mathrm{mg}$ daily, $0.5 \mathrm{mg}$ daily and aminoglutethimide in postmenopausal women with advanced breast cancer. Annals of Oncology 9 639-645.

Goss PE \& Strasser K 2001 Aromatase inhibitors in the treatment and prevention of breast cancer. Journal of Clinical Oncology 19 881-894.

Haddow A, Watkinson JM \& Paterson E 1944 Influence of synthetic oestrogens upon advanced malignant disease. British Medical Journal 2 393-398.

HarperWynne C \& Coombes RC 1999 Anastrozole shows evidence of activity in postmenopausal patients who have responded or stabilised on formestane therapy. European Journal of Cancer 35 744-746.

Howell A, Robertson JF, Quaresma Albano J, Aschermannova A, Mauriac L, Kleeberg UR, Vergote I, Erikstein B, Webster A \& Morris C 2002 Fulvestrant, formerly ICI 182,780, is as effective as anastrozole in postmenopausal women with advanced breast cancer progressing after prior endocrine treatment. Journal of Clinical Oncology 20 3396-3403.

Ingle JN, Ahmann DL, Green SJ, Edmonson JH, Bisel HF, Kvols LK, Nichols WC, Creagan ET, Hahn RG, Rubin J \& Frytak S 1981 Randomized clinical trial of diethylstilstilbestrol versus tamoxifen in postmenopausal women with advanced breast cancer. New England Journal of Medicine 304 16-21.

Jacobs S, Lønning PE, Haynes B, Griggs L \& Dowsett M 1991 Measurement of aromatisation by a urine technique suitable for the evaluation of aromatase inhibitors in vivo. Journal of Enzyme Inhibition 4 315-325.

Jakesz R, Hausmaninger H, Kubista E, Gnant M, Menzel C, Bauernhofer T, Seifert M, Haider K, Mlineritsch B, Steindorfer P, Kwasny W, Fridrik M, Steger G, Wette V \& Samonigg H 2002 Randomized adjuvant trial of tamoxifen and goserelin versus cyclophosphamide, methotrexate, and fluorouracil: evidence for the superiority of treatment with endocrine blockade in premenopausal patients with hormoneresponsive breast cancer - Austrian Breast and Colorectal
Cancer Study Group Trial 5. Journal of Clinical Oncology 20 4621-4627.

James VHT, Reed MJ, Adams EF, Ghilchik M, Lai LC, Coldham NG, Newton CJ, Purohit A, Owen AM, Singh CJ \& Islam S 1989 Oestrogen uptake and metabolism in vivo. Oestrogens and the human breast. Proceedings of the Royal Society of Edinburgh 95B 185-193.

Johannessen DC, Engan T, Salle Ed, Zurlo MG, Paolini J, Ornati G, Piscitelli G, Kvinnsland S \& Lønning PE 1997 Endocrine and clinical effects of exemestane (PNU 155971), a novel steroidal aromatase inhibitor, in postmenopausal breast cancer patients: a phase I study. Clinical Cancer Research 3 1101-1108.

Jonat W, Kaufmann M, Sauerbrei W, Blamey R, Cuzick J, Namer M, Fogelman I, de Haes JC, de Matteis A, Stewart A, Eiermann W, Szakolczai I, Palmer M, Schumacher M, Geberth M \& Lisboa B 2002 Goserelin versus cyclophosphamide, methotrexate, and fluorouracil as adjuvant therapy in premenopausal patients with nodepositive breast cancer: the Zoladex Early Breast Cancer Research Association Study. Journal of Clinical Oncology 20 4628-4635.

Jones AL, MacNeill F, Jacobs S, Lønning PE, Dowsett M \& Powles TJ 1992 The influence of intramuscular 4-hydroxyandrostenedione on peripheral aromatisation in breast cancer patients. European Journal of Cancer 28A 1712-1716.

Kaufmann M, Bajetta E, Dirix LY, Fein LE, Jones SE, Zilembo N, Dugardyn J-L, Nasurdi C, Mennel RG, Cervek J, Fowst C, Polli A, Di Salle E, Arkhipov A, Piscitelli G, Miller LL \& Massimini G 2000 Exemestane is superior to megestrol acetate after tamoxifen failure in postmenopausal women with advanced breast cancer: results of a phase III randomized double-blind trial. Journal of Clinical Oncology 18 1399-1411.

Key TJ, Appleby PN, Reeves GK, Roddam A, Dorgan JF, Longcope C, Stanczyk FZ, Stephenson HE, Falk RT, Miller R, Schatzkin A, Allen DS, Fentiman IS, Wang DY, Dowsett M, Thomas HV, Hankinson SE, Toniolo P, Koenig K, Shore RE, Zeleniuch-Jacquotte A, Berrino F, Muti P, Micheli A, Krogh V, Sieri S, Pala V, Venturelli E, Secreto G, BarrettConnor E, Laughlin GA, Kabuto M, Akiba S, Stevens RG, Neriishi K, Land CE, Cauley JA, Kuller LH, Cummings SR, Helzlsouer KJ, Alberg AJ, Bush TL, Comstock GW, Gordon GB \& Miller SR 2003 Body mass index, serum sex hormones, and breast cancer risk in postmenopausal women. Journal of the National Cancer Institute 95 1218-1226.

Klijn JGM, Blamey RW, Boccardo F, Tominaga T, Duchateau L \& Sylvester R 2001 Combined tamoxifen and luteinizing hormone-releasing hormone (LHRH) agonist versus LHRH agonist alone in premenopausal advanced breast cancer: a meta-analysis of four randomized trials. Journal of Clinical Oncology 19 343-353.

van Landeghem AAJ, Poortman J, Nabuurs M \& Thijssen JHH 1985 Endogenous concentration and subcellular distribution of estrogens in normal and malignant breast tissue. Cancer Research 45 2900-2904. 
Lea OA, Kvinnsland S \& Thorsen T 1989 Improved measurement of androgen receptors in human breast cancer. Cancer Research 49 7162-7167.

Lippman M, Bolan G \& Huff K 1976 The effects of estrogens and antiestrogens on hormone-responsive human breast cancer in long-term tissue culture. Cancer Research 36 4595-4601.

Lønning PE 1996 Pharmacology of new aromatase inhibitors. Breast 5 202-208.

Lønning PE 2001 Stepwise estrogen suppression manipulating the estrostat. Journal of Steroid Biochemistry and Molecular Biology 79 127-132.

Lønning PE 2002 Aromatase inhibitors and inactivators for breast cancer therapy. Drugs and Aging 19 277-298.

Lønning PE \& Ekse D 1995 A sensitive assay for measurement of plasma estrone sulphate in patients on treatment with aromatase inhibitors. Journal of Steroid Biochemistry and Molecular Biology 55 409-412.

Lønning PE, Dowsett M \& Powles TJ 1990 Postmenopausal estrogen synthesis and metabolism: alterations caused by aromatase inhibitors used for the treatment of breast cancer. Journal of Steroid Biochemistry 35 355-366.

Lønning PE, Jacobs S, Jones A, Haynes B, Powles T \& Dowsett M 1991 The influence of CGS 16949A on peripheral aromatisation in breast cancer patients. British Journal of Cancer 63 789-793.

Lønning PE, Bajetta E, Murray R, Tubiana-Hulin M, Eisenberg PD, Mickiewicz E, Celio L, Pitt P, Mita M, Aaronson NK, Fowst C, Arkhipov A, di Salle E, Polli A \& Massimini G 2000 Activity of exemestane (Aromasin ${ }^{\circledR}$ ) in metastatic breast cancer after failure of nonsteroidal aromatase inhibitors: a phase II trial. Journal of Clinical Oncology 18 2234-2244.

Lønning PE, Taylor PD, Anker G, Iddon J, Wie L, Jørgensen LM, Mella O \& Howell A 2001 High-dose estrogen treatment in postmenopausal breast cancer patients heavily exposed to endocrine treatment. Breast Cancer Research and Treatment $67111-116$

MacNeill FA, Jones AL, Jacobs S, Lønning PE, Powles TJ \& Dowsett M 1992 The influence of aminoglutethimide and its analogue rogletimide on peripheral aromatisation in breast cancer. British Journal of Cancer 66 692-697.

MacNeill FA, Jacobs S, Dowsett M, Lønning PE \& Powles TJ 1995 The effects of oral 4-hydroxyandrostenedione on peripheral aromatisation in post-menopausal breast cancer patients. Cancer Chemotherapy and Pharmacology 36 249-254.

Masamura S, Santner SJ, Heitjan DF \& Santen RJ 1995 Estrogen deprivation causes estradiol hypersensitivity in human breast cancer cells. Journal of Clinical Endocrinology and Metabolism 80 2918-2925.

Masamura S, Santner SJ, Gimotty P, George J \& Santen RJ 1997 Mechanism for maintenance of high breast tumor estradiol concentrations in the absence of ovarian function: role of very high affinity tissue uptake. Breast Cancer Research and Treatment 42 215-226.

Matsumine H, Hirato K, Yanaihara T, Tamada T \& Yoshida M 1984 Aromatization by skeletal muscle. Journal of Clinical Endocrinology and Metabolism 63 717-720.

Miller WR1989 Aromatase inhibitors in the treatment of advanced breast cancer. Cancer Treatment Review 16 83-93.
Miller WR 1994 Importance of intratumour aromatase, and its susceptibility to inhibitors. In Aromatase Inhibition - Then, Now and Tomorrow, pp 43-53. Ed. M Dowsett. London: Parthenon Publishing Group.

Miller WR \& Dixon JM 2000 Antiaromatase agents: preclinical data and neoadjuvant therapy. Clinical Breast Cancer $\mathbf{1}$ (Suppl 1) 9-14.

Miller WR \& Dixon JM 2001 Local endocrine effects of aromatase inhibitors within the breast. Journal of Steroid Biochemistry and Molecular Biology 79 93-102.

Miller WR, Anderson TJ \& Jack WJL 1990 Relationship between tumour aromatase activity, tumour characteristics and response to therapy. Journal of Steroid Biochemistry and Molecular Biology 37 1055-1059.

Miller WR, Telford J, Love C, Leonard RCF, Hillier S, Gundacker H, Smith H \& Dixon JM 1998 Effects of letrozole as primary medical therapy on in situ oestrogen synthesis and endogenous oestrogen levels within the breast. Breast 7 273-276.

Mouridsen H, Gershanovich M, Sun Y, Pérez-Carrión R, Boni C, Monnier A, Apffelstaedt J, Smith R, Sleeboom HP, Jänicke F, Pluzanska A, Dank M, Becquart D, Bapsy PP, Salminen E, Snyder R, Lassus M, Verbeek JA, Staffler B, Chaudri-Ross HA \& Dugan M 2001 Superior efficacy of letrozole versus tamoxifen as first-line therapy for postmenopausal women with advanced breast cancer: results of a phase III study of the International Letrozole Breast Cancer Group. Journal of Clinical Oncology 19 2596-2606.

Murray R \& Pitt P 1995 Aromatase inhibition with 4OHandrostenedione after prior aromatase inhibition with aminoglutethimide in women with advanced breast cancer. Breast Cancer Research and Treatment 35 249-253.

Nabholtz JM, Buzdar A, Pollak M, Harwin W, Burton G, Mangalik A, Steinberg M, Webster A \& von Euler M 2000 Anastrozole is superior to tamoxifen as first-line therapy for advanced breast cancer in postmenopausal women: results of a North American multicenter randomized trial. Journal of Clinical Oncology 18 3758-3767.

Njar VCO \& Brodie AMH 1999 Comprehensive pharmacology and clinical efficacy of aromatase inhibitors. Drugs $\mathbf{5 8}$ 233-255.

Nosaquo ND 1960 Androgens and estrogens in the treatment of disseminated mammary carcinoma. Journal of the American Medical Association 172 135-147.

Perel E \& Killinger DW 1978 The interconversion and aromatization of androgens by human adipose tissue. Journal of Steroid Biochemistry 10 623-627.

Perel E, Blackstein ME \& Killinger DW 1982 Aromatase in human breast carcinoma. Cancer Research 42 (Suppl) 3369-3372.

Pérez-Carrión R, Candel VA, Calabresi F, Michel RT, Santos R, Delozier T, Goss P, Mauriac L, Feuilhade F, Freue M, Pannuti F, Belle SV, Martinez J, Wehrle E \& Royce CM 1994 Comparison of the selective aromatase inhibitor formestane with tamoxifen as first-line hormonal therapy in postmenopausal women with advanced breast cancer. Annals of Oncology 5 (Suppl) 19-24.

Pizzagalli F, Varga Z, Huber RD, Folkers G, Meier PJ \& St-Pierre MV 2003 Identification of steroid sulfate transport 
processes in the human mammary gland. Journal of Clinical Endocrinology and Metabolism 88 3902-3912.

Reed MJ, Owen AM, Lai LC, Coldham NG, Ghilchik MW, Shaikh NA \& James VHT 1989 In situ oestrone synthesis in normal breast and breast tumour tissue; effect of treatment with 4-hydroxyandrostenedione. International Journal of Cancer 44 233-237.

Reed MJ, Aherne GW, Ghilchik MW, Patel S \& Chakraborty J 1991 Concentrations of oestrone and 4hydroxyandrostenedione in malignant and normal breast tissue. International Journal of Cancer 49 562-565.

Reed MJ, Topping L, Coldham NG, Purohit A, Ghilchik MW \& James VHT 1993 Control of aromatase activity in breast cancer cells: the role of cytokines and growth factors. Journal of Steroid Biochemistry and Molecular Biology 44 589-596.

Santen RJ, Santner S, Davis B, Veldhuis J, Samojlik E \& Ruby E 1978 Aminoglutethimide inhibits extraglandular estrogen production in postmenopausal women with breast carcinoma. Journal of Clinical Endocrinology and Metabolism $\mathbf{4 7}$ $1257-1265$.

Santen RJ, Worgul TJ, Lipton A, Harvey H \& Boucher A 1982 Aminoglutethimide as treatment of postmenopausal women with advanced breast carcinoma. Annals of Internal Medicine 96 94-101.

Santner SJ, Leszcynski D, Wright C, Manni A, Feil PD \& Santen RJ 1986 Estrone sulfate: a potential source of estradiol in human breast cancer tissue. Breast Cancer Research and Treatment 7 35-44.

Schweikert HU, Milewich L \& Wilson JD 1976 Aromatization of androstenedione by cultured human fibroblasts. Journal of Clinical Endocrinology and Metabolism 43 785-795.

Simpson E, Jones M, Davis S \& Rubin G 1999 Do intracrine mechanisms regulate aromatase expression? Journal of Steroid Biochemistry and Molecular Biology 69 447-452.

Singh A, Purohit A, Ghilchik MW \& Reed MJ 1999 The regulation of aromatase activity in breast fibroblasts: the role of interleukin-6 and prostaglandin E2. Endocrine-Related Cancer 6 139-147.

Sluijmer AV, Heineman MA, Jong FHD \& Evers JLH 1995 Endocrine activity of the postmenopausal ovary: the effects of pituitary down-regulation and oophorectomy. Journal of Clinical Endocrinology and Metabolism 80 2163-2167.

Smith IE \& Dowsett M 2003 Drug therapy: aromatase inhibitors in breast cancer. New England Journal of Medicine 348 2431-2442.
Smuk M \& Schwers J 1977 Aromatization of androstenedione by human adult liver in vitro. Journal of Clinical Endocrinology and Metabolism 45 1009-1012.

Thürlimann B, Beretta K, Bacchi M, Castiglionegertsch M, Goldhirsch A, Jungi WF, Cavalli F, Senn HJ, Fey M \& Lohnert T 1996 First-line fadrozole HCI (CGS 16949A) versus tamoxifen in postmenopausal women with advanced breast cancer - prospective randomised trial of the Swiss Group for Clinical Cancer Research SAKK 20/88. Annals of Oncology 7 471-479.

Thürlimann B, Castiglione M, HsuSchmitz SF, Cavalli F, Bonnefoi H, Fey MF, Morant R, Lohnert T \& Goldhirsch A $1997 a$ Formestane versus megestrol acetate in postmenopausal breast cancer patients after failure of tamoxifen: a phase III prospective randomised cross over trial of second-line hormonal treatment (SAKK 20/90). European Journal of Cancer 33 1017-1024.

Thürlimann B, Paridaens R, Serin D, Bonneterre J, Roche H, Murray R, diSalle E, Lanzalone S, Zurlo MG \& Piscitelli G $1997 b$ Third-line hormonal treatment with exemestane in postmenopausal patients with advanced breast cancer progressing on aminoglutethimide: a phase II multicentre multinational study. European Journal of Cancer $\mathbf{3 3}$ 1767-1773.

Vermeulen A, Deslypere JP, Paridaens R, Leclerco G, Roy F \& Heuson JC 1985 Aromatase, 17ß-hydroxysteroid dehydrogenase and intratissular sex hormone concentrations in cancerous and normal glandular breast tissue in postmenopausal women. European Journal of Cancer and Clinical Oncology 22 515-525.

Zhang YQ, Kiel DP, Kreger BE, Cupples LA, Ellison RC, Dorgan JF, Schatzkin A, Levy D \& Felson DT 1997 Bone mass and the risk of breast cancer among postmenopausal women. New England Journal of Medicine 336 611-617.

Zhao Y, Mendelson CR \& Simpson ER 1995 Characterization of the sequences of the human CYP19 (aromatase) gene that mediate regulation by glucocorticoids in adipose stromal cells and fetal hepatocytes. Molecular Endocrinology 9 340-349.

Zhao Y, Nichols JE, Valdez R, Mendelson CR \& Simpson ER 1996 Tumor necrosis factor-alpha stimulates aromatase gene expression in human adipose stromal cells through use of an activating protein-1 binding site upstream of promoter 1.4. Molecular Endocrinology 10 1350-1357. 